\title{
Insulin/IGF-driven cancer cell-stroma crosstalk as a novel therapeutic target in pancreatic cancer
}

\author{
Ayse Ceren Mutgan ${ }^{1}$, H. Erdinc Besikcioglu ${ }^{1,2}$, Shenghan Wang ${ }^{1}$, Helmut Friess ${ }^{1}$, Güralp O. Ceyhan ${ }^{1}$ \\ and Ihsan Ekin Demir ${ }^{1 *}$
}

\begin{abstract}
Pancreatic ductal adenocarcinoma (PDAC) is unrivalled the deadliest gastrointestinal cancer in the western world. There is substantial evidence implying that insulin and insulin-like growth factor (IGF) signaling axis prompt PDAC into an advanced stage by enhancing tumor growth, metastasis and by driving therapy resistance. Numerous efforts have been made to block Insulin/IGF signaling pathway in cancer therapy. However, therapies that target the IGF1 receptor (IGF-1R) and IGF subtypes (IGF-1 and IGF-2) have been repeatedly unsuccessful. This failure may not only be due to the complexity and homology that is shared by Insulin and IGF receptors, but also due to the complex stroma-cancer interactions in the pancreas. Shedding light on the interactions between the endocrine/ exocrine pancreas and the stroma in PDAC is likely to steer us toward the development of novel treatments. In this review, we highlight the stroma-derived IGF signaling and IGF-binding proteins as potential novel therapeutic targets in PDAC.
\end{abstract}

Keywords: IGF-1, Insulin, Pancreatic cancer, Stroma

\section{Background}

The latest demographic studies on pancreatic ductal adenocarcinoma (PDAC) indicate that, unless novel diagnostic tools and treatments are developed, PDAC is expected to be the 2nd leading cancer-related cause of death in the United States before 2030 [1].

Smoking, alcohol usage, family history of chronic pancreatitis, male gender, advanced age, high body mass index (BMI) and diabetes mellitus (DM) are risk factors for developing PDAC [2, 3]. Among these, type 2 DM/T2DM has been postulated to be a reason for screening for PDAC, as it frequently precedes the diagnosis of PDAC [4]. Thus, researchers have long wondered whether T2DM is a contributor or a consequence of the PDAC.

Most T2DM patients have hyperinsulinemia, a condition that defines high insulin levels in the blood. Insulin regulates glucose, lipid and amino acid homeostasis, acts on organs such as liver, muscle and adipose tissue

\footnotetext{
* Correspondence: ekin.demir@tum.de

${ }^{1}$ Department of Surgery, Klinikum rechts der Isar, Technical University

Munich, München, Germany

Full list of author information is available at the end of the article
}

lifelong. In a state of hyperinsulinemia, insulin increases bio-availability of another class of factors, i.e. insulin-like growth factors (IGF), which are one of the key regulators of energy metabolism and growth [5].

Due to the plethora of metabolic derangements caused by hyperinsulinemia, researchers have long considered a potentially decisive role for Insulin/IGF signaling in neoplasia, including PDAC [6]. Although the first results of the clinical trials with compounds that target insulin/ IGF signaling in PDAC have been disappointing, researchers have recently directed their research towards understanding the role of Insulin/IGF-1R signaling in the cross-talk between cancer cells and stroma. Indeed, there is still a major knowledge gap in how exactly the dynamic stroma of PDAC can affect the complex endocrine and exocrine compartments of the pancreas. Thus, enlightening the insulin/IGF-driven interaction between cancer cells, endocrine pancreas, and the stroma may be key to understanding the progression of PDAC and of PDAC-associated diabetes, and thereby open the door to the development of efficent therapies that target cancer cells and tumor stroma at the same time. In this review, 
we summarize the role of Insulin/IGF signaling pathway in the reciprocal interactions of stromal cells with cancer cells in the PDAC microeinvironment and suggest a research line to that may create opportunities to develop novel treatments for PDAC.

\section{Tumor cell-intrinsic effects of IGF signaling in PDAC}

Insulin and IGF are closely related and conserved systemic growth factors that are produced by different organs. Insulin is produced by $\beta$-cells of the pancreas, and IGF ligands IGF-1 and IGF- 2 are produced by the liver in response to growth hormone $(\mathrm{GH})$ stimulation that is secreted from the anterior pituitary gland [6]. Insulin (IR) and IGF (IGFR) receptors belong to the receptor tyrosine kinase (RTK) family. There are two different insulin receptors and two different IGF receptors, IR-A/ IR-B and IGF-1R/IGF-2R, respectively. IGF-1R is expressed nearly in all tissues $[7,8]$. Moreover, $40-90 \%$ of the IGF-1R on tissues are found to be IGF-1R/IR hybrid receptors [7, 8]. Such hybrid receptors display higher binding affinity to IGF ligands compared to insulin [9]. IGF-2R is ubiquitously expressed, and yet IGF-2R receptor activation does not induce activation of insulin/IGF signaling axis [6]. IGF-2R can only bind to IGF-2, but insulin, IGF-1 and IGF-2 can bind to IR, IGF-1R and IR/ IGF-1R hybrid receptors with varying binding affinity (Fig. 1) [10-12]. Thus, the crosstalk between insulin and IGF signaling axis designates the complexity of this signaling pathway and its numerous modes of activation.

IGF-1 and IGF-1R are known to be abundantly expressed in the PDAC tissue, and activated Insulin/IGF signaling in PDAC cells was found to regulate the basal growth rate of the cancer cells [13, 14]. In fact, IGF-1R expression is correlated with higher tumor grade, and its co-expression with epidermal growth factor receptor (EGFR) was shown to be be significantly associated with poor survival in PDAC [15]. IGF-2R mRNA and protein levels were previously shown to be upregulated in human pancreatic cancer tissues, particuarly in the nucleus of ductal-like pancreatic cancer cells, when compared to the normal pancreatic tissue [16]. When the inability of IGF-2R to induce Insulin/IGF signaling is considered, IGF-2R seems to decrease the bioavailability of IGF-2 in the circulation and attenuates insulin/IGF signaling axis by clearance of the circulating IGF-2.

IGF signaling pathway further consists of six IGF binding proteins (IGFBPs) and 10 IGFBP-related proteins (IGFBP-rPs) [17]. In circulation, IGFs are found in a protein-bound form with IGFBPs [18], protecting the ligands from degradation, and extending the half-life and stability of the circulating IGFs [17, 19]. Free IGFs have a higher binding affinity to IGFBPs than to IGF-1R, IR and IR/IGF-1R hybrid receptors. Therefore, distribution of IGFs in tissues and attenuation of the Insulin/IGF signaling is regulated by IGFBPs, which regulate the bioavailability of IGFs and contribute to attenuation of the Insulin/IGF signaling axis $[17,19,20]$.In the serum and in the pancreas of PDAC patients, IGFBP-1, IGFBP-3, IGF-1 and IGF1R are over-expressed [21]. In addition, high IGF-1 levels in the serum of PDAC patients are associated with high levels of IGFBP-3 again in the serum when compared to healthy individuals [22]. Besides, increase in the serum levels of IGFBP-3 seems to be associated with the risk of death from PDAC [22]. Recent studies highlighted that high IGF-1/low IGFBP-3 concentrations might be associated with increased PDAC risk [23, 24]. Accordingly, patients with high IGF-1R/low IGFBP-3 expression in the pancreas are diagnosed with advanced PDAC and exhibit overall poor survival [25]. This observation suggests that IGF-1/IGFBP-3 expression levels might be altered during the progression of PDAC, but, most importantly, elevated levels of free IGF-1 together with IGF-1R expression is correlated with poor prognosis and survival. In addition, IGFBP-3 is one of the p53 response genes and is involved in p53induced apoptosis independent of IGF-1 signaling [26]. Interestingly, p53 can also directly modulate IGF-1R expression by regulating the IGF-1R gene promoter [27].Therefore, inactivation or altered expression of tumor suppressors such as p53 might be another reason for the overexpression of IGF-1R receptors in PDAC.

\section{IGF signaling in the PDAC stroma}

Despite the presence of several studies that demonstrated the effects of activated IGF signaling on cancer cells in PDAC, the impact of stromal IGF signaling or stroma-derived IGFs in PDAC has been recognized only very recently. PDAC cells are typically surrounded by a dense stroma, which is classically assumed to serve as a protective barrier against tumor spread [28, 29]. The majority of tumor stroma in PDAC is composed of "acellular" components. i.e. extracelluar matrix proteins such as collagen, fibronectin or laminin, The "cellular" stroma contains the key actors of the tumor microenvironment such as immune cells, endothelial cells, pancreatic stellate cells, fibroblasts, or neural cells. There are five lines of evidence that suggests a key role for stromal IGF signaling in the progression of PDAC (Figs. 2, 3).

\section{Activated stromal (myo-) fibroblasts as a leading source of IGF-1 in PDAC}

In more than $90 \%$ of PDAC cases, KRAS is overactivated by mutations [30]. KRAS ${ }^{(\mathrm{G} 12 \mathrm{D})}$-mutated cancer cells activate stromal fibroblasts via Sonic Hedgehog (Shh) pathway [31]. This activation does not only provide survival signals for the fibroblasts, but also activates IGF-1R on cancer cells via IGF-1 that is secreted by fibroblasts and by pancreatic stellate cells (PaSCs) in 


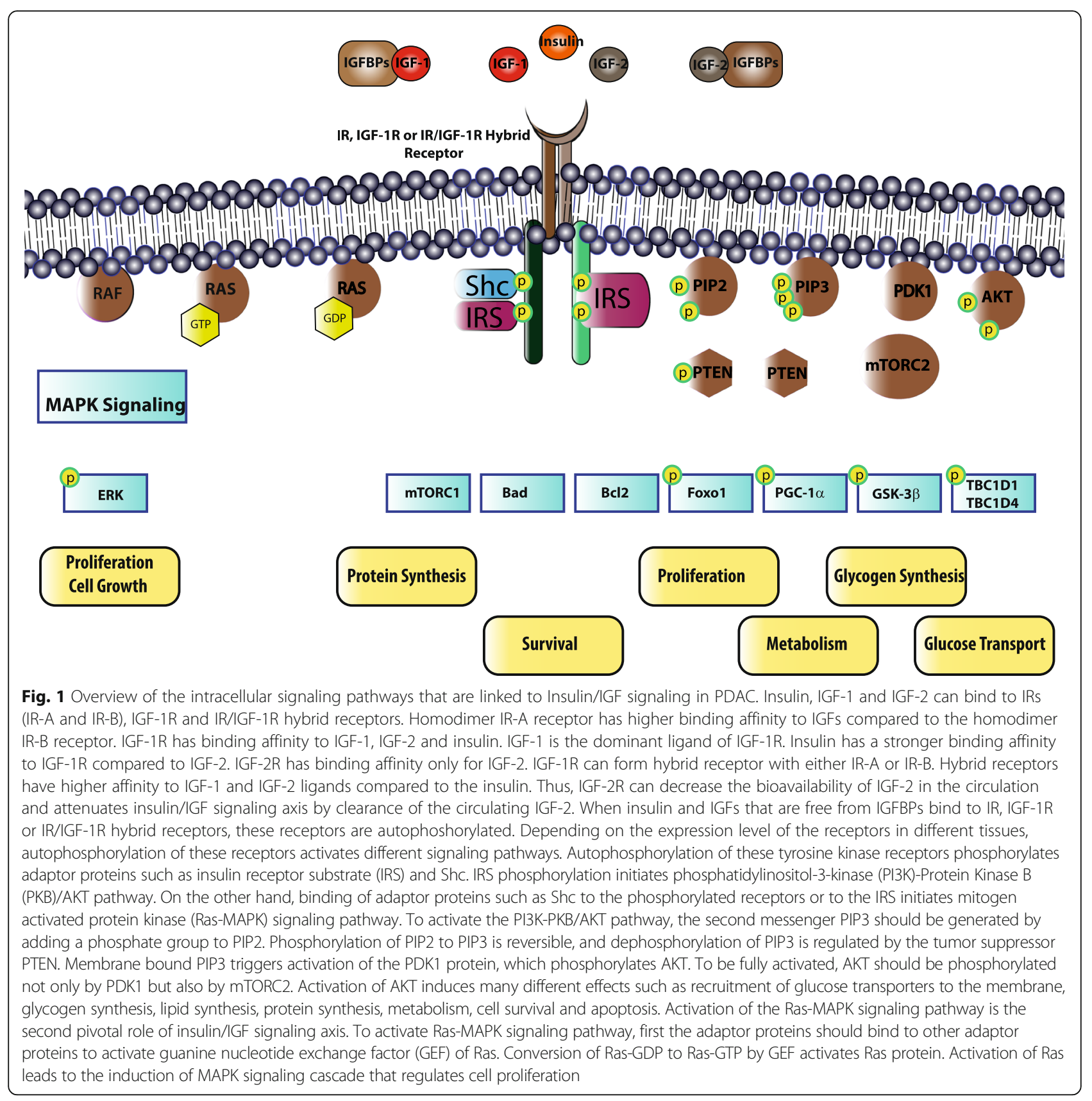

response to Shh (Fig. 2) [31-33]. Indeed, current evidence suggests that stromal cells may be the foremost source of IGF-1 in the PDAC microenvironment. IGFs that are secreted from stromal cells can act on cancer cells via direct IGF-1R signaling, and together with hepatocyte growth factor/HGF, can phosphorylate Annexin A2/AnxA2, a protein that has a well-established role in invasion/metastasis [33].

In addition to Shh, stromal (myo-) fibroblasts can also become activated under tumor hypoxia. Indeed, PDACs are hypovascularized and thus hypoxic tumors [34]. In PDAC, cancer-associated fibroblasts produce IGF-1 under hypoxic conditions and promote tumor cell migration via IGF-1R signaling under hypoxia in vitro [34]. Remarkably, the migration capacity of tumor-derived PaSCs is also prominently greater both at basal conditions and after IGF-1 stimulation [35]. One molecular reason for this may be the expression levels of IGFBP in PaSCs: Tumor PaSCs have lower expression levels of IGFBP-3 and higher expression levels of IGFBP-2 compared to the normal PaSCs. Considering the greater migratory capacity of tumor PaSCs when compared to normal PaSCs, the reduction in IGFBP-3 levels seems to overweigh the elevation of IGFBP-2, resulting in a net increase in the IGF-1 availability [35]. 


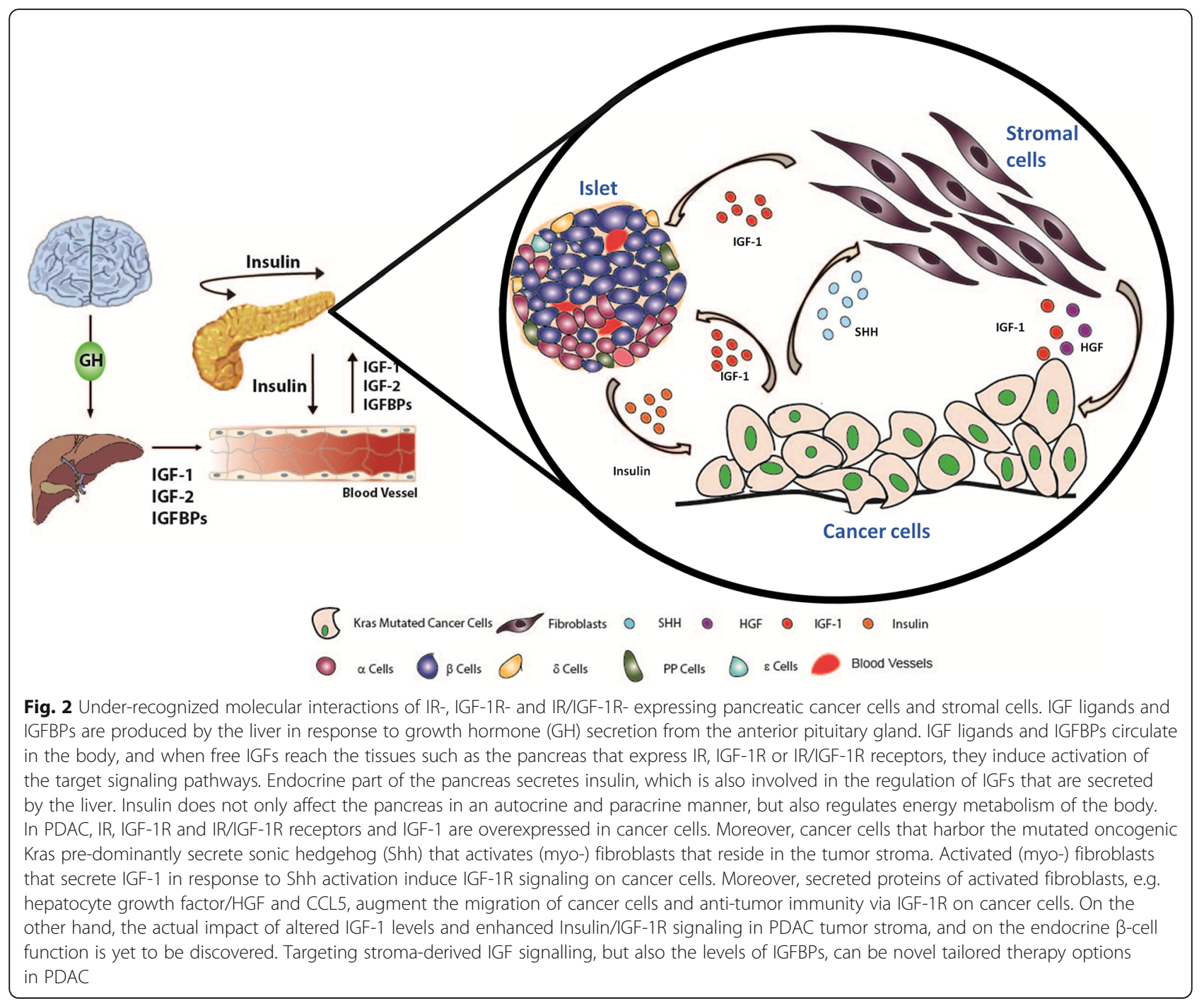

\section{Control of IGFBP levels by stromal proteases}

Expression levels of the regulatory IGFBPs in the liver and concentration of these proteins in circulation or in the tumor tissue are subject to modulation via proteases [36]. Importantly, the desmoplastic pancreatic cancer stroma contains many different proteases. Such proteases may cause degradation of IGFBPs and lead to increased amounts of free IGFs within the tissue. For instance, nerve growth factor (NGF), a family member of kallikrein proteases, can degrade IGFBP-3, IGFBP-4 and IGFBP-6 and is strongly upregulated in PDAC [37, 38]. Similarly, cathepsin D, which also displays high expression levels in PDAC patients compared to healthy individuals, can mediate proteolysis of IGFBPs $[39,40]$. Likewise, IGFBP-1, $-2,-3,-4$ and -6 , are substrates of MMP-2, MMP-7 and MMP-9 proteases, which are expressed in the peritumoral stroma and cancer cells in PDAC [41-44]. Direct modulation of IGFBPs at protein level via stromal proteases can be considered as one of the sources of activated IGF signaling in PDAC.
Regulation of anti-tumor immunity in PDAC stroma by IGF signaling

The dynamic stroma can also regulate anti-tumor immunity [45]. Wide range of studies have implied the involvement of CCL5/CCR5 signaling axis in antitumor immunity, invasion and metastasis [46]. Interestingly, IGF-1 maintains secretion of CCL5 from stromal cells, in particular mesenchymal stem cells that are in physical contact with PDAC cancer cells in vitro, resulting in the recruitment of tumortargeting immune cells [47]. Importantly, active signalling through IGF-1R is needed for this cross-talk [46, 47]. Like pancreatic myofibroblasts, tumor associated macrophages (TAMs) are the other stromal source of IGF ligands [48]. Recently, it has been found that TAM infiltration in PDAC patients is correlated with increased IR/IGF-1R expression, and inhibition of IR/IGF-1R axis in preclinical diseases models improves chemotherapy responses [48]. 


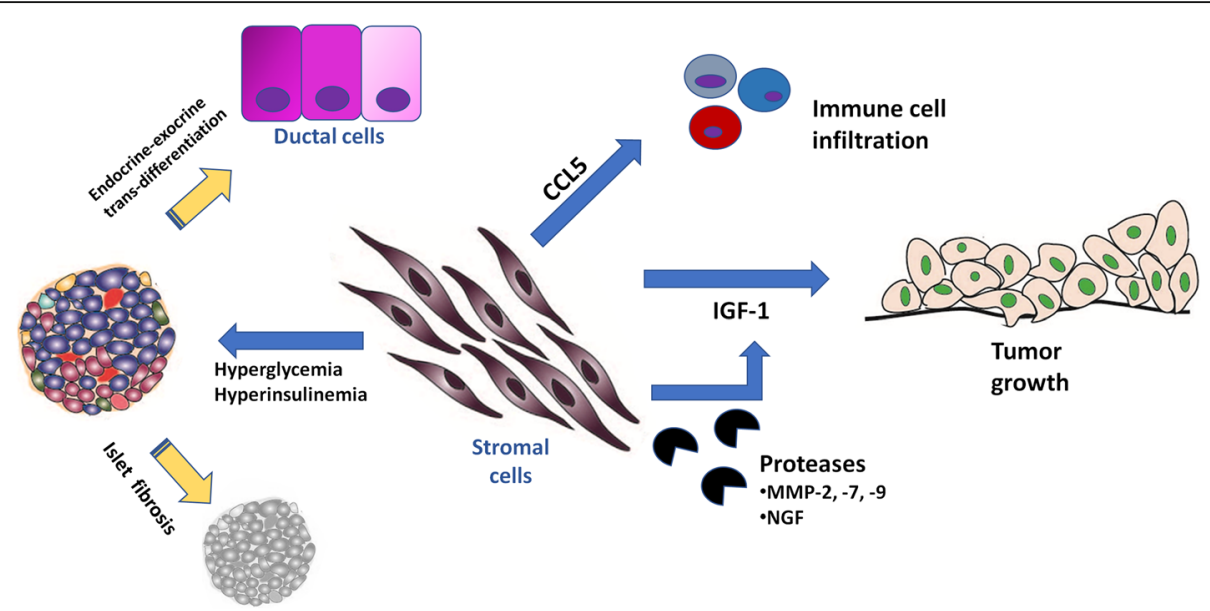

Fig. 3 Five lines of evidence supporting a key role for stroma-derived IGF signaling in PDAC. 1) Stromal cells such as fibroblasts or pancreatic stellate cells (PaSCs) can secrete IGF-1 and enhance the migration capacity of PDAC cells. 2) Proteases such as MMP-3, MMP-7, or MMP-9 that are secreted by stromal cells can cleave IGFBPs and thereby fine-tune IGF activity. 3) Via chemokine secretion, stromal cells can chemo-attract immune cells such as macrophages to the tumor microenvironment and can thereby influence the local tumor control. 4) In a hyperglycaemic state that frequently accompanies PDAC, stromal cells can become activated and cause islet fibrosis and thereby aggravate the hyperglycaemic state. 5) Increasing tissue damage and fibrosis can lead to recruitment of endocrine or exocrine progenitors that can result in transdifferentiation between these cell types

\section{Hyperinsulinemia promotes stromal activation and fibrosis in PDAC}

Western-type high fat diet can result in, hyperinsulinemia, and over time lead to hyperglycemia due to insulin resistance, and particularly to elevated IGF-1 levels in the circulation. This metabolic derangement was shown to activate PaSCs that express IR-A and IGF-1 receptors [49], and to boost stromal fibrosis and also specifically fibrosis within islets, which is typically encountered in T2DM [50, 51].

\section{Impact on the exocrine-endocrine crosstalk in PDAC}

Previous studies suggested that insulin/IGF signaling can affect both the exocrine and endocrine compartment of the pancreas. In the exocrine compartment, IGF-1 is mainly responsible for acinar cell regeneration and regulation of amylase synthesis [52]. Indeed, IGF-1 that is secreted from fibroblasts was shown to promote acinar cell recovery during acute pancreatitis [53]. Besides, IGF-1 can reduce the tissue damage due to caeruleininduced pancreatitis [54]. Moreover, after partial pancreatectomy in mice, acinar cell proliferation was linked to IGF-1 presence in the microenvironment and was hampered in aging mice due to the loss of responsiveness to IGF-1 $[55,56]$.

The impact of Insulin/IGF signalling on development and function of the endocrine pancreas has been extensively studied and summarized before [57-59]. In the endocrine compartment, IGFs, IGF-1R and IGFBPs were shown to control the function of $\beta$-cells. IGF-1 can stimulate $\beta$-cell proliferation and increase $\beta$-cell mass, increase basal insulin production regardless of mass proliferation
[60-63]. Furthermore, low levels of circulating IGF-1 reduces $\beta$-cells function [64]. On the other hand, IGF-2 ligand overexpression has been found to damage the function of $\beta$-cells in vivo [65]. Interestingly, IGFBP-3 also affects $\beta$-cells. In vitro studies suggested that IGFBP-3 can trigger apoptosis in insulin-secreting cells [66]. Moreover, IGFBP-3 is able to regulate insulin secretion from $\beta$-cells in response to glucose, in vivo [67].

Substantial evidence suggests that both endocrine islets and exocrine pancreas tissue can modulate each other's function. Earlier studies that had been conducted with mouse models of type I diabetes mellitus, disclosed that hormone secretion from islets modulate the structure and the functionallity of exocrine cells in the pancreas [68-71]. Interestingly, in mouse models of type II diabetes mellitus and in diabetic patients, extracellular matrix in-between islets and acinar cells is frequently lost [72]. Tissue fibrosis and pericapillary fibrosis in the islets lead to loss of cell to cell communication between islets and acinar cells [72]. Thus, this phenomenon may not only alter the trophic effects of the endocrine cells on the exocrine cells, but also diminish the efficent use of digestive enzymes by gut and thereby cause maldigestion [72]. Besides, it is also imaginable that alterations in IGFBP levels in the PDAC stroma can be indirectly responsible for loss of islets and emergence of diabetes and maldigestion in PDAC. Of note, one should consider that endocrine $\beta$-cells that express oncogenic K-ras can also be one potential progenitor for PDAC under chronic tissue inflammation [73]. Overexpression of transcription factors that normally control endocrine differentiation during embryonic development (i.e., 
Neruogenin 3, Pax6, MafA, Pdx1) in ductal cells can lead to exocrine-endocrine differentiation [74-76]. Moreover, ductal cells are able to undergo ductal-endocrine differentiation in the presence of proinflammotary cytokines such as TNF- $\alpha$, IL- $1 \beta$ and IFN- $\gamma$ via STAT3 activation [77]. Interestingly, endocrine progenitors like Sox $9(+) / \mathrm{Pdx} 1$ $(+) / \mathrm{Ngn} 3(+)$ cells are found in the intercalated ducts of adult pancreata [78]. Moreover, patients with chronic pancreatitis were reported to have insulin-expressing 'islet progenitors' on their ducts [79]. Whether such cells are present in the PDAC stroma has yet to be invesigated. The function of these insulin-expressing cells on pancreatic ducts in the normal and diseased pancreas is also currently unknown. Moreover, the potential role of insulin-secreting endocrine cells in the progression of PDAC and the impact of PDAC tumor microenvironment on insulin-secreting endocrine cells is yet to be discovered. Such a "three-way", insulin/IGF-driven interaction between exocrine/cancer cells, endocrine pancreas, and the stroma may be key to understanding the progression of PDAC and of PDAC-associated diabetes (Fig. 3).

\section{The impact of insulin/IGF-1R signaling on chemotherapy and targeted therapies in PDAC: current and novel directions}

PDAC is frequently resistant to the current chemotherapy regimens. Recently, FOLFIRINOX, a novel chemotherapy regimen containing four different chemotherapy drugs (follinic acid, fluorouracil, oxaliplatin and irinotecan) was reported to increase the overall survival of patients with unresectable metastatic PDAC to 11.1 months from 6.8 months, a success rate that is far from being satisfying [80]. This fact points out the urgent need of developing novel treatment strategies or novel targeted therapeutics.

There is accumulating evidence suggesting that IGF-1R pathway inhibitors may enable conceivable benefits in PDAC treatment. Aiming to overcome chemotherapy resistance and to develop better adjuvant therapies within the last decade, many different small molecule inhibitors/ monoclonal antibodies against IGF-1R and neutralizing antibodies against IGF ligands have been developed and tested in pre-clinical studies. Even though promising results were obtained with the developed compounds during in vitro, during pre-clinical studies in vivo, and at Phase I/ Phase II clinical trials, the overall outcome of advanced clinical trials is yet disappointing. Table 1 provides a comprehensive overview of clinical trials that target insulin/ IGF signalling in pancreatic cancer (Table 1).

Insulin/IGF-1R signaling is one of the signaling pathways that govern the sensitization of cancer cells to gemcitabine $[48,81]$. Secreted IGFs from activated myofibroblasts directly act on IGF-1R, which promotes resistance to gemcitabine in pre-clinical studies $[48,81]$. However, combined administration of gemcitabine with ganitumab, a monoclonal antibody that inhibits IGF-1R activity, did not show any significant improvement in the survival of PDAC patients (Table 1) [82]. In another strategy, gemcitabine in combination with cetuximab, an epidermal growth factor receptor (EGFR) inhibitor, also failed to show any improvement in survival during Phase II/Phase III trials [83]. Recently, MM-141, a tetravalent bispecific antibody that recognizes IGF-1R and EGFR family member ErbB3, provided promising results in pre-clinical studies [84]. Currently, MM-141 is being tested in Phase II clinical trials in combination with Nabpaclitaxel plus gemcitabine (Table 1, NCT02399137). As another approach, researchers have been testing the effect of another IGF-1R monoclonal antibody, MK-0646, in combination with gemcitabine and erlotinib, an RTK inhibitor that targets EGFR (Table 1, NCT00769483). Even though dual inhibition of IGF-1R/EGFR sounds promising, one should remember that IGF-1R and IR show high homology. Hence, even if IGF-1R receptors are inhibited together with other receptors that promote PDAC progression, IR receptors and hybrid IR/IGF-1R receptors that show strong resemblance to IGF-1R, can be still active and take over the function of the blocked IGF-1R receptor in the presence of insulin or IGFs. Blockade of insulin receptors may have wide-ranging systemic side effects, such as hyperglycemia. One way to overcome this problem is to use specific neutralizing antibodies against IGF-1/IGF-2. Indeed, in pre-clinical studies, cancer proliferation and tumor-promoting effects of mTOR signaling are reduced by BI836845, a neutralizing antibody against IGFs [85]. Phase I clinical trials of this agent in combination with other drugs in non-small-cell lung cancer and prostate cancer are ongoing (NCT02191891 and NCT02204072, respectively). However, studies that investigate the efficacy of this agent in PDAC currently do not exist.

Multiple trials testing therapy regimens that combine conventional cytotoxic drugs with molecules that target IGF-1R signaling have failed to show a major impact on the natural progression of PDAC. Although dual inhibition of IGF-1R signaling together with another RTK that is involved in PDAC progression is the current focus, it is crucial to choose the best partner to inhibit. Moreover, most of the compounds that target IGF-1R signaling either inhibit specifically IGF-1R activation or neutralize IGF-1 and IGF-2. Researchers have not known whether neutralizing antibodies are efficient and completely block the side effects of elevated levels of IGFs in the tissue. Besides, the source and the function of the increased amounts of IGFs in cancer stroma has only been recently identified. Pancreas is a complex tissue, and we should build on our knowledge on the impact of enhanced IGF-1R signaling on the "three-way", insulin/ IGF-driven interaction between cancer cells, endocrine pancreas, and the stroma. 


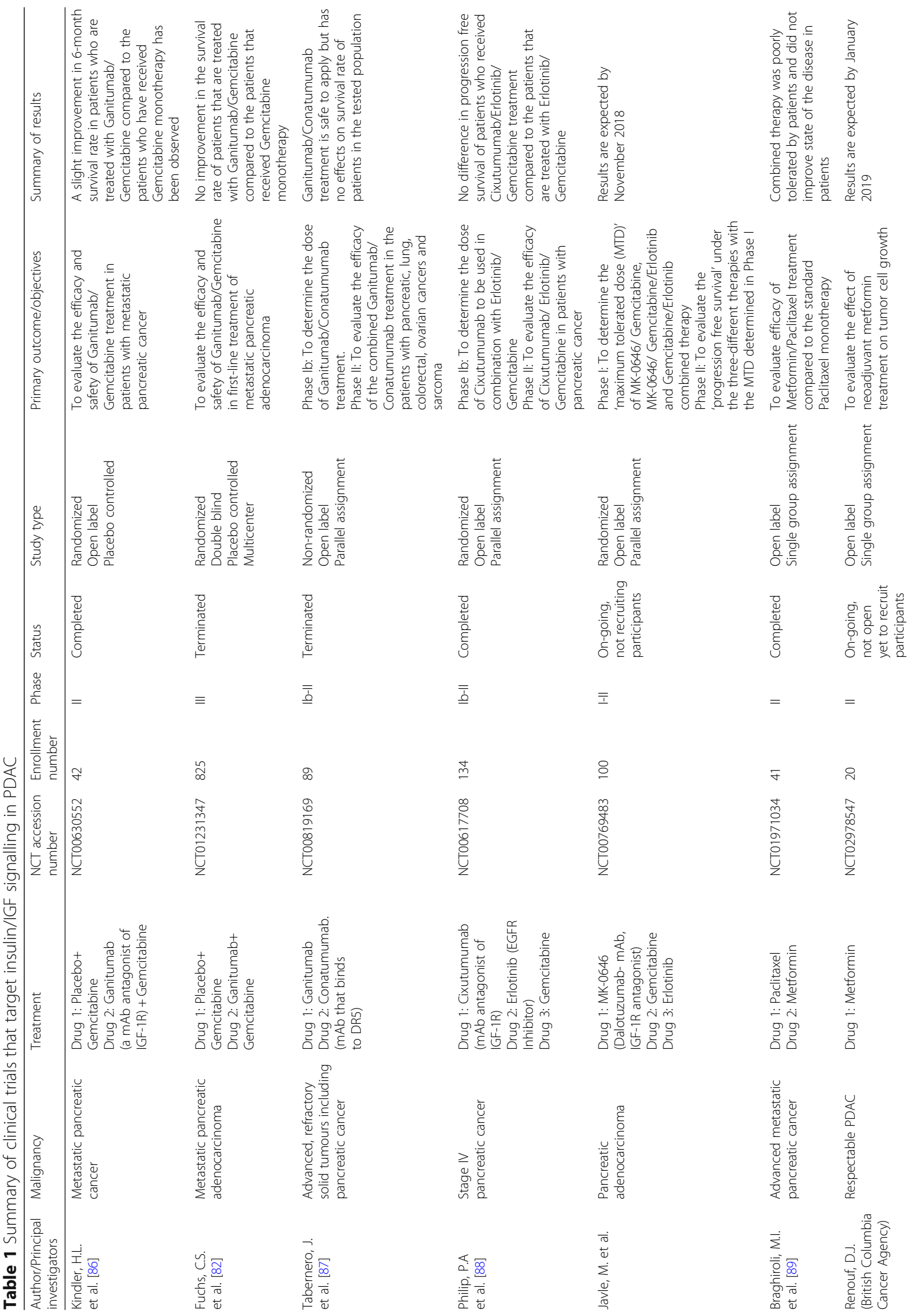




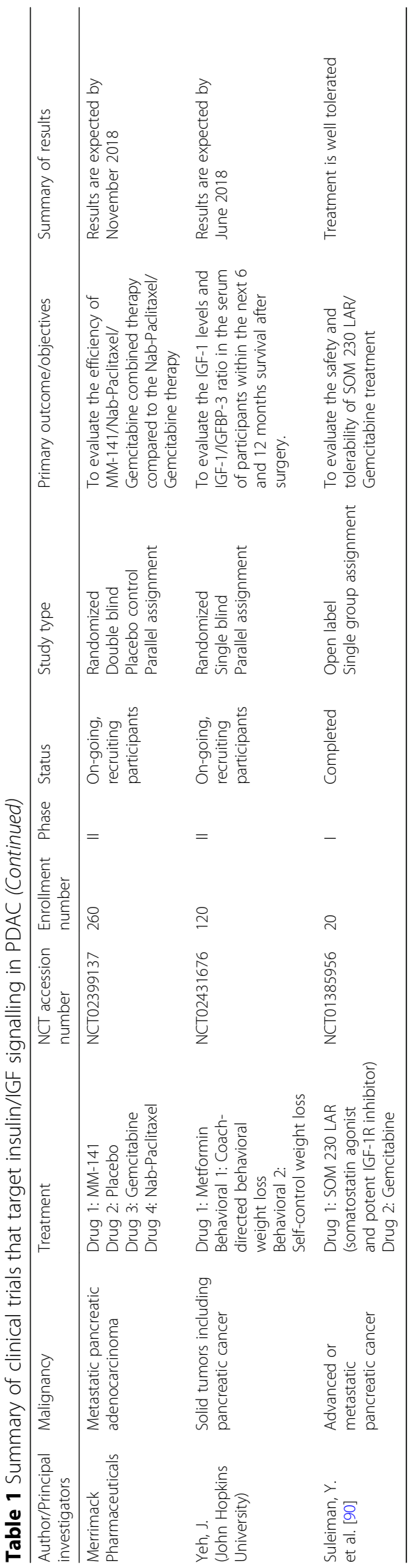


Based on the knowledge depicted above, we propose that 1) specific targeting of stroma-cell-derived IGFs, and 2) targeting the levels of stroma-derived IGFBPs can have more promising traits in the therapy of PDAC. Focusing more on this phenomenon can help researchers to identifty novel therapy targets for dual inhibition IGF$1 \mathrm{R}$ signaling, and other signaling pathways, and thereby can create an oppurtunity for dual targeting of stroma and cancer cells.

\section{Conclusion}

Insulin/IGF-1R signaling axis is one of the multiple dysregulated pathways in PDAC, and its roles in the progression of PDAC seem to be multifold. Although there are enormous efforts to develop novel targeted therapies against this signaling axis, recent clinical trials have not been successful. Evidence from cancers other than PDAC suggest that usage of neutralizing agents against IGF-1/IGF-2 can be a promising approach. However, an under-investigated niche is the role of stromal insulin/ IGF-1 signaling and the contribution of IGFBPs. Tailored, targeted therapies against stromal insulin/IGF-1 signaling can have beneficial effects both on cancer progression and the deregulated endocrine function. Thus, targeting the stromal activity of this pathway may be a novel, viable option in the future treatment of PDAC.

\section{Authors' contributions}

ACM, HEB and IED drafted the first version of the manuscript, SW contributed with literature search and review. HF and GOC supervised the review process. All authors have critically reviewed and approved the manuscript.

\section{Competing interests}

All authors declare that they have no competing interests.

\section{Publisher's Note}

Springer Nature remains neutral with regard to jurisdictional claims in published maps and institutional affiliations.

\section{Author details}

${ }^{1}$ Department of Surgery, Klinikum rechts der Isar, Technical University Munich, München, Germany. ${ }^{2}$ Department of Histology and Embryology, Gazi University Institute of Health Sciences, Ankara, Turkey.

Received: 22 April 2017 Accepted: 1 February 2018

Published online: 23 February 2018

\section{References}

1. Rahib L, Smith BD, Aizenberg R, Rosenzweig AB, Fleshman JM, Matrisian LM. Projecting cancer incidence and deaths to 2030: the unexpected burden of thyroid, liver, and pancreas cancers in the United States. Cancer Res. 2014;74(11):2913-21.

2. Gong J, Robbins LA, Lugea A, Waldron RT, Jeon CY, Pandol SJ. Diabetes, pancreatic cancer, and metformin therapy. Front Physiol. 2014;5:426

3. Vincent A, Herman J, Schulick R, Hruban RH, Goggins M. Pancreatic cancer. Lancet. 2011;378(9791):607-20.

4. Onitilo AA, Engel JM, Glurich I, Stankowski RV, Williams GM, Doi SA. Diabetes and cancer I: risk, survival, and implications for screening. Cancer Causes Control. 2012;23(6):967-81.

5. Cotterill AM, Holly JM, Wass JA. The regulation of insulin-like growth factor binding protein (IGFBP)-1 during prolonged fasting. Clin Endocrinol. 1993;39(3):357-62.
6. Pollak M. Insulin and insulin-like growth factor signalling in neoplasia. Nat Rev Cancer. 2008;8(12):915-28.

7. Bailyes EM, Nave BT, Soos MA, Orr SR, Hayward AC, Siddle K. Insulin receptor/IGFreceptor hybrids are widely distributed in mammalian tissues: quantification of individual receptor species by selective immunoprecipitation and immunoblotting. Biochem J. 1997;327(Pt 1):209-15.

8. Federici M, Porzio O, Zucaro L, Fusco A, Borboni P, Lauro D, Sesti G. Distribution of insulin/insulin-like growth factor-l hybrid receptors in human tissues. Mol Cell Endocrinol. 1997;129(2):121-6.

9. Boucher J, Kleinridders A, Kahn CR. Insulin receptor signaling in normal and insulin-resistant states. Cold Spring Harb Perspect Biol. 2014;6(1).

10. Belfiore A, Frasca F, Pandini G, Sciacca L, Vigneri R. Insulin receptor isoforms and insulin receptor/insulin-like growth factor receptor hybrids in physiology and disease. Endocr Rev. 2009;30(6):586-623.

11. Rajapaksha $H$, Forbes BE. Ligand-binding affinity at the insulin receptor Isoform-a and subsequent IR-A tyrosine Phosphorylation kinetics are important determinants of Mitogenic biological outcomes. Front Endocrinol (Lausanne). 2015:6:107.

12. Siddle K. Signalling by insulin and IGF receptors: supporting acts and new players. J Mol Endocrinol. 2011;47(1):R1-10.

13. Bergmann U, Funatomi H, Yokoyama M, Beger HG. K M: insulin-like growth factor I Overexpression in human pancreatic cancer: evidence for Autocrine and Paracrine roles. Cancer Res. 1995;55:5.

14. Ohmura E, Okada M, Onoda N, Kamiya Y, Murakami H, Tsushima T, Shizume K. Insulin-like growth factor I and transforming growth factor alpha as autocrine growth factors in human pancreatic cancer cell growth. Cancer Res. 1990:50(1):103-7.

15. Valsecchi ME, McDonald M, Brody JR, Hyslop T, Freydin B, Yeo CJ, Solomides C, Peiper SC, Witkiewicz AK. Epidermal growth factor receptor and insulinlike growth factor 1 receptor expression predict poor survival in pancreatic ductal adenocarcinoma. Cancer. 2012;118(14):3484-93.

16. Ishiwata T, Bergmann U, Kornmann M, Lopez M, Beger HG, Korc M. Altered expression of insulin-like growth factor $\|$ receptor in human pancreatic cancer. Pancreas. 1997;15(4):367-73.

17. Brahmkhatri VP, Prasanna C, Atreya HS. Insulin-like growth factor system in cancer: novel targeted therapies. Biomed Res Int. 2015;2015:538019.

18. Ouyang H, Shiwaku HO, Hagiwara H, Miura K, Abe T, Kato Y, Ohtani H, Shiiba K, Souza RF, Meltzer SJ, et al. The insulin-like growth factor II receptor gene is mutated in genetically unstable cancers of the endometrium, stomach, and colorectum. Cancer Res. 1997:57(10):1851-4.

19. Firth SM, Baxter RC. Cellular actions of the insulin-like growth factor binding proteins. Endocr Rev. 2002;23(6):824-54

20. Baxter RC. IGF binding proteins in cancer: mechanistic and clinical insights. Nat Rev Cancer. 2014;14(5):329-41.

21. Karna E, Surazynski A, Orlowski K, Laszkiewicz J, Puchalski Z, Nawrat P, Palka J. Serum and tissue level of insulin-like growth factor-I (IGF-I) and IGF-I binding proteins as an index of pancreatitis and pancreatic cancer. Int J Exp Pathol. 2002;83(5):239-45.

22. Lin Y, Tamakoshi A, Kikuchi S, Yagyu K, Obata Y, Ishibashi T, Kawamura T, Inaba Y, Kurosawa M, Motohashi Y, et al. Serum insulin-like growth factor-I, insulin-like growth factor binding protein-3, and the risk of pancreatic cancer death. Int J Cancer. 2004;110(4):584-8.

23. Rohrmann S, Grote VA, Becker S, Rinaldi S, Tjonneland A, Roswall N, Gronbaek H, Overvad K, Boutron-Ruault MC, Clavel-Chapelon F, et al. Concentrations of IGF-I and IGFBP-3 and pancreatic cancer risk in the European prospective investigation into cancer and nutrition. $\mathrm{Br} J$ Cancer. 2012;106(5):1004-10.

24. Douglas JB, Silverman DT, Pollak MN, Tao Y, Soliman AS, Stolzenberg-Solomon RZ. Serum IGF-I, IGF-II, IGFBP-3, and IGF-I/IGFBP-3 molar ratio and risk of pancreatic cancer in the prostate, lung, colorectal, and ovarian cancer screening trial. Cancer Epidemiol Biomark Prev. 2010;19(9):2298-306.

25. Hirakawa T, Yashiro M, Murata A, Hirata K, Kimura K, Amano R, Yamada N, Nakata B, Hirakawa K. IGF-1 receptor and IGF binding protein-3 might predict prognosis of patients with resectable pancreatic cancer. BMC Cancer. 2013;13:392.

26. Grimberg A, Liu B, Bannerman P, El-Deiry WS, Cohen P. IGFBP-3 mediates p53-induced apoptosis during serum starvation. Int J Oncol. 2002;21(2):327-35.

27. Werner H, Karnieli E, Rauscher FJ, LeRoith D. Wild-type and mutant p53 differentially regulate transcription of the insulin-like growth factor receptor gene. Proc Natl Acad Sci U S A. 1996;93(16):8318-23.

28. Ozdemir BC, Pentcheva-Hoang T, Carstens JL, Zheng X, Wu CC, Simpson TR, Laklai H, Sugimoto H, Kahlert C, Novitskiy SV, et al. Depletion of carcinoma- 
associated fibroblasts and fibrosis induces immunosuppression and accelerates pancreas cancer with reduced survival. Cancer Cell. 2014;25(6):719-34.

29. Rhim AD, Oberstein PE, Thomas DH, Mirek ET, Palermo CF, Sastra SA, Dekleva EN, Saunders T, Becerra CP, Tattersall IW, et al. Stromal elements act to restrain, rather than support, pancreatic ductal adenocarcinoma. Cancer Cell. 2014:25(6):735-47.

30. Eser S, Schnieke A, Schneider G, Saur D. Oncogenic KRAS signalling in pancreatic cancer. Br J Cancer. 2014;111(5):817-22.

31. Tape CJ, Ling S, Dimitriadi M, McMahon KM, Worboys JD, Leong HS, Norrie IC, Miller CJ, Poulogiannis G, Lauffenburger DA, et al. Oncogenic KRAS regulates tumor cell signaling via Stromal reciprocation. Cell. 2016;165(4):910-20.

32. Scales SJ, de Sauvage FJ. Mechanisms of hedgehog pathway activation in cancer and implications for therapy. Trends Pharmacol Sci. 2009;30(6):303-12.

33. Rucki AA, Foley K, Zhang P, Xiao Q, Kleponis J, Wu AA, Sharma R, Mo G, Liu A, Van Eyk J, et al. Heterogeneous Stromal signaling within the tumor microenvironment controls the metastasis of pancreatic cancer. Cancer Res. 2017;77(1):41-52.

34. Hirakawa T, Yashiro M, Doi Y, Kinoshita H, Morisaki T, Fukuoka T, Hasegawa T, Kimura K, Amano R, Hirakawa K. Pancreatic fibroblasts stimulate the motility of pancreatic cancer cells through IGF1/IGF1R signaling under hypoxia. PLoS One. 2016;11(8):e0159912.

35. Rosendahl AH, Gundewar C, Said Hilmersson K, Ni L, Saleem MA, Andersson R. Conditionally immortalized human pancreatic stellate cell lines demonstrate enhanced proliferation and migration in response to IGF-I. Exp Cell Res. 2015;330(2):300-10

36. Rajah R, Katz L, Nunn S, Solberg P, Beers T, Cohen P. Insulin-like growth factor binding protein (IGFBP) proteases: functional regulators of cell growth. Prog Growth Factor Res. 1995;6(2-4):273-84.

37. Ceyhan GO, Schafer KH, Kerscher AG, Rauch U, Demir IE, Kadihasanoglu M, Bohm C, Muller MW, Buchler MW, Giese NA, et al. Nerve growth factor and artemin are paracrine mediators of pancreatic neuropathy in pancreatic adenocarcinoma. Ann Surg. 2010;251(5):923-31.

38. Rajah R, Bhala A, Nunn SE, Peehl DM, Cohen P. 7S nerve growth factor is an insulin-like growth factor-binding protein protease. Endocrinology. 1996;137(7):2676-82.

39. Braulke T, Claussen M, Saftig P, Wendland M, Neifer K, Schmidt B, Zapf J, von Figura K, Peters C. Proteolysis of IGFBPs by cathepsin D in vitro and in cathepsin D-deficient mice. Prog Growth Factor Res. 1995;6(2-4): 265-71.

40. Park HD, Kang ES, Kim JW, Lee KT, Lee KH, Park YS, Park JO, Lee J, Heo JS, Choi SH, et al. Serum CA19-9, cathepsin D, and matrix metalloproteinase-7 as a diagnostic panel for pancreatic ductal adenocarcinoma. Proteomics. 2012;12(23-24):3590-7.

41. Jakubowska K, Pryczynicz A, Januszewska J, Sidorkiewicz I, Kemona A, Niewinski A, Lewczuk L, Kedra B, Guzinska-Ustymowicz K. Expressions of matrix Metalloproteinases 2, 7, and 9 in carcinogenesis of pancreatic Ductal Adenocarcinoma. Dis Markers. 2016;2016:9895721.

42. Miyamoto S, Yano K, Sugimoto S, Ishii G, Hasebe T, Endoh Y, Kodama K, Goya M, Chiba T, Ochiai A. Matrix metalloproteinase-7 facilitates insulin-like growth factor bioavailability through its proteinase activity on insulin-like growth factor binding protein 3. Cancer Res. 2004;64(2):665-71.

43. Miyamoto S, Nakamura M, Yano K, Ishii G, Hasebe T, Endoh Y, Sangai T, Maeda H, Shi-Chuang Z, Chiba T, et al. Matrix metalloproteinase-7 triggers the matricrine action of insulin-like growth factor-II via proteinase activity on insulin-like growth factor binding protein 2 in the extracellular matrix. Cancer Sci. 2007;98(5):685-91.

44. Prudova A, auf dem Keller U, Butler GS, Overall CM. Multiplex N-terminome analysis of MMP-2 and MMP-9 substrate degradomes by iTRAQ-TAILS quantitative proteomics. Mol Cell Proteomics. 2010;9(5):894-911.

45. Hanahan D, Weinberg RA. Hallmarks of cancer: the next generation. Cell. 2011;144(5):646-74.

46. Aldinucci D, Colombatti A. The inflammatory chemokine CCL5 and cancer progression. Mediat Inflamm. 2014;2014:292376.

47. Makinoshima H, Dezawa M. Pancreatic cancer cells activate CCL5 expression in mesenchymal stromal cells through the insulin-like growth factor-I pathway. FEBS Lett. 2009;583(22):3697-703.

48. Ireland L, Santos A, Ahmed MS, Rainer C, Nielsen SR, Quaranta V, Weyer-Czernilofsky U, Engle DD, Perez-Mancera PA, Coupland SE, et al. Chemoresistance in pancreatic cancer is driven by Stroma-derived insulin-like growth factors. Cancer Res. 2016;76(23):6851-63.
49. Yang J, Waldron RT, Su HY, Moro A, Chang HH, Eibl G, Ferreri K, Kandeel FR, Lugea A, Li L, et al. Insulin promotes proliferation and fibrosing responses in activated pancreatic stellate cells. Am J Physiol Gastrointest Liver Physiol. 2016:311(4):G675-87.

50. Kikuta K, Masamune A, Hamada S, Takikawa T, Nakano E, Shimosegawa T. Pancreatic stellate cells reduce insulin expression and induce apoptosis in pancreatic beta-cells. Biochem Biophys Res Commun. 2013;433(3):292-7.

51. Zang G, Sandberg M, Carlsson PO, Welsh N, Jansson L, Barbu A. Activated pancreatic stellate cells can impair pancreatic islet function in mice. Ups J Med Sci. 2015;120(3):169-80.

52. Mossner J, Logsdon CD, Goldfine ID, Williams JA. Do insulin and the insulin like growth factors (IGFs) stimulate growth of the exocrine pancreas? Gut. 1987;28(Suppl):51-5.

53. Ludwig CU, Menke A, Adler G, Lutz MP. Fibroblasts stimulate acinar cell proliferation through IGF-I during regeneration from acute pancreatitis. Am J Phys. 1999;276(1 Pt 1):G193-8.

54. Warzecha Z, Dembinski A, Ceranowicz P, Konturek SJ, Tomaszewska R, Stachura J, Konturek PC. IGF-1 stimulates production of interleukin-10 and inhibits development of caerulein-induced pancreatitis. J Physiol Pharmacol. 2003;54(4):575-90.

55. Watanabe H, Saito H, Rychahou PG, Uchida T, Evers BM. Aging is associated with decreased pancreatic acinar cell regeneration and phosphatidylinositol 3-kinase/Akt activation. Gastroenterology. 2005;128(5):1391-404.

56. Takahashi H, Okamura D, Starr ME, Saito H, Evers BM. Age-dependent reduction of the PI3K regulatory subunit p85alpha suppresses pancreatic acinar cell proliferation. Aging Cell. 2012;11(2):305-14.

57. Kulkarni RN. Receptors for insulin and insulin-like growth factor-1 and insulin receptor substrate-1 mediate pathways that regulate islet function. Biochem Soc Trans. 2002;30(2):317-22.

58. Kulkarni RN. The islet beta-cell. Int J Biochem Cell Biol. 2004;36(3):365-71.

59. Kulkarni RN. New insights into the roles of insulin/IGF-I in the development and maintenance of beta-cell mass. Rev Endocr Metab Disord. 2005;6(3):199-210.

60. Cordoba-Chacon J, Majumdar N, Pokala NK, Gahete MD, Kineman RD. Islet insulin content and release are increased in male mice with elevated endogenous GH and IGF-I, without evidence of systemic insulin resistance or alterations in beta-cell mass. Growth Hormon IGF Res. 2015;25(4):189-95.

61. Agudo J, Ayuso E, Jimenez V, Salavert A, Casellas A, Tafuro S, Haurigot V, Ruberte J, Segovia JC, Bueren J, et al. IGF-I mediates regeneration of endocrine pancreas by increasing beta cell replication through cell cycle protein modulation in mice. Diabetologia. 2008;51(10):1862-72.

62. Ma F, Wei Z, Shi C, Gan Y, Lu J, Frank SJ, Balducci J, Huang Y. Signaling cross talk between growth hormone $(\mathrm{GH})$ and insulin-like growth factor-I (IGF-I) in pancreatic islet beta-cells. Mol Endocrinol. 2011;25(12):2119-33.

63. Escribano O, Gomez-Hernandez A, Diaz-Castroverde S, Nevado C, Garcia G, Otero YF, Perdomo L, Beneit N, Benito M. Insulin receptor isoform a confers a higher proliferative capability to pancreatic beta cells enabling glucose availability and IGF-I signaling. Mol Cell Endocrinol. 2015;409:82-91.

64. Thankamony A, Capalbo D, Marcovecchio ML, Sleigh A, Jorgensen SW, Hill NR, Mooslehner K, Yeo GS, Bluck L, Juul A, et al. Low circulating levels of IGF-1 in healthy adults are associated with reduced beta-cell function, increased intramyocellular lipid, and enhanced fat utilization during fasting. J Clin Endocrinol Metab. 2014;99(6):2198-207.

65. Casellas A, Mallol C, Salavert A, Jimenez V, Garcia M, Agudo J, Obach M, Haurigot V, Vila L, Molas M, et al. Insulin-like growth factor 2 Overexpression induces Beta-cell dysfunction and increases beta-cell susceptibility to damage. J Biol Chem. 2015;290(27):16772-85.

66. Shim ML, Levitt Katz LE, Davis J, Dotzler WC, Cohen P, Ferry RJ Jr. Insulin-like growth factor binding protein-3 is a novel mediator of apoptosis in insulin-secreting cells. Growth Hormon IGF Res. 2004;14(3):216-25.

67. Nguyen $\mathrm{KH}$, Yao XH, Moulik S, Mishra S, Nyomba BL. Human IGF binding protein-3 overexpression impairs glucose regulation in mice via an inhibition of insulin secretion. Endocrinology. 2011;152(6):2184-96.

68. Trajkovic-Arsic M, Kalideris E, Siveke JT. The role of insulin and IGF system in pancreatic cancer. J Mol Endocrinol. 2013;50(3):R67-74.

69. Barreto SG, Carati CJ, Toouli J, Saccone GT. The islet-acinar axis of the pancreas: more than just insulin. Am J Physiol Gastrointest Liver Physiol. 2010;299(1):G10-22

70. Lankisch PG, Manthey G, Otto J, Koop H, Talaulicar M, Willms B, Creutzfeldt W. Exocrine pancreatic function in insulin-dependent diabetes mellitus. Digestion. 1982;25(3):211-6.

71. Frier BM, Saunders JH, Wormsley KG, Bouchier IA. Exocrine pancreatic function in juvenile-onset diabetes mellitus. Gut. 1976;17(9):685-91. 
72. Hayden MR, Patel K, Habibi J, Gupta D, Tekwani SS, Whaley-Connell A, Sowers JR. Attenuation of endocrine-exocrine pancreatic communication in type 2 diabetes: pancreatic extracellular matrix ultrastructural abnormalities. J Cardiometab Syndr. 2008;3(4):234-43.

73. Gidekel Friedlander SY, Chu GC, Snyder EL, Girnius N, Dibelius G, Crowley D, Vasile E, DePinho RA, Jacks T. Context-dependent transformation of adult pancreatic cells by oncogenic K-Ras. Cancer Cell. 2009;16(5):379-89.

74. Azzarelli R, Hurley C, Sznurkowska MK, Rulands S, Hardwick L, Gamper I, Ali F, McCracken L, Hindley C, McDuff F, et al. Multi-site Neurogenin3 Phosphorylation controls pancreatic endocrine differentiation. Dev Cell. 2017;41(3):274-86. e275

75. Lee J, Sugiyama T, Liu Y, Wang J, Gu X, Lei J, Markmann JF, Miyazaki S, Miyazaki J, Szot GL, et al. Expansion and conversion of human pancreatic ductal cells into insulin-secreting endocrine cells. elife. 2013;2:e00940.

76. Smith SB, Watada H, German MS. Neurogenin3 activates the islet differentiation program while repressing its own expression. Mol Endocrinol. 2004;18(1):142-9.

77. Valdez IA, Dirice E, Gupta MK, Shirakawa J, Teo AKK, Kulkarni RN. Proinflammatory cytokines induce endocrine differentiation in pancreatic Ductal cells via STAT3-dependent NGN3 activation. Cell Rep. 2016;15(3):460-70.

78. Carpino G, Renzi A, Cardinale V, Franchitto A, Onori P, Overi D, Rossi M, Berloco PB, Alvaro D, Reid LM, et al. Progenitor cell niches in the human pancreatic duct system and associated pancreatic duct glands: an anatomical and immunophenotyping study. J Anat. 2016;228(3):474-86.

79. Phillips JM, O'Reilly L, Bland C, Foulis AK, Cooke A. Patients with chronic pancreatitis have islet progenitor cells in their ducts, but reversal of overt diabetes in NOD mice by anti-CD3 shows no evidence for islet regeneration. Diabetes. 2007;56(3):634-40.

80. Conroy T, Desseigne F, Ychou M, Bouche O, Guimbaud R, Becouarn Y Adenis A, Raoul JL, Gourgou-Bourgade S, de la Fouchardiere C, et al. FOLFIRINOX versus gemcitabine for metastatic pancreatic cancer. N Engl J Med. 2011;364(19):1817-25.

81. Tian X, Hao K, Qin C, Xie K, Xie X, Yang Y. Insulin-like growth factor 1 receptor promotes the growth and chemoresistance of pancreatic cancer. Dig Dis Sci. 2013;58(9):2705-12.

82. Fuchs CS, Azevedo S, Okusaka T, Van Laethem JL, Lipton LR, Riess $H$, Szczylik C, Moore MJ, Peeters M, Bodoky G, et al. A phase 3 randomized, double-blind, placebo-controlled trial of ganitumab or placebo in combination with gemcitabine as first-line therapy for metastatic adenocarcinoma of the pancreas: the GAMMA trial. Ann Oncol. 2015;26(5):921-7.

83. Philip PA, Benedetti J, Corless CL, Wong R, O'Reilly EM, Flynn PJ, Rowland KM, Atkins JN, Mirtsching BC, Rivkin SE, et al. Phase III study comparing gemcitabine plus cetuximab versus gemcitabine in patients with advanced pancreatic adenocarcinoma: southwest oncology group-directed intergroup trial S0205. J Clin Oncol. 2010;28(22):3605-10.

84. Fitzgerald JB, Johnson BW, Baum J, Adams S, ladevaia S, Tang J, Rimkunas V, Xu L, Kohli N, Rennard R, et al. MM-141, an IGF-IR- and ErbB3-directed bispecific antibody, overcomes network adaptations that limit activity of IGF-IR inhibitors. Mol Cancer Ther. 2014;13(2):410-25.

85. Friedbichler K, Hofmann MH, Kroez M, Ostermann E, Lamche HR, Koessl C, Borges E, Pollak MN, Adolf G, Adam PJ. Pharmacodynamic and Antineoplastic activity of BI 836845, a fully human IGF Ligand-neutralizing antibody, and mechanistic rationale for combination with Rapamycin. Mol Cancer Ther. 2014;13(2):399-409.

86. Kindler HL, Richards DA, Garbo LE, Garon EB, Stephenson JJ Jr, Rocha-Lima CM, Safran H, Chan D, Kocs DM, Galimi F, et al. A randomized, placebo-controlled phase 2 study of ganitumab (AMG 479) or conatumumab (AMG 655) in combination with gemcitabine in patients with metastatic pancreatic cancer. Ann Oncol. 2012;23(11):2834-42.

87. Tabernero J, Chawla SP, Kindler H, Reckamp K, Chiorean EG, Azad NS, Lockhart AC, Hsu CP, Baker NF, Galimi F, et al. Anticancer activity of the type I insulin-like growth factor receptor antagonist, ganitumab, in combination with the death receptor 5 agonist, conatumumab. Target Oncol. 2015;10(1):65-76.

88. Philip PA, Goldman B, Ramanathan RK, Lenz HJ, Lowy AM, Whitehead RP, Wakatsuki T, lqbal S, Gaur R, Benedetti JK, et al. Dual blockade of epidermal growth factor receptor and insulin-like growth factor receptor-1 signaling in metastatic pancreatic cancer: phase Ib and randomized phase II trial of gemcitabine, erlotinib, and cixutumumab versus gemcitabine plus erlotinib (SWOG S0727). Cancer. 2014;120(19):2980-5.

89. Braghiroli MI, de Celis Ferrari AC, Pfiffer TE, Alex AK, Nebuloni D, Carneiro AS, Caparelli F, Senna L, Lobo J, Hoff PM, et al. Phase II trial of metformin and paclitaxel for patients with gemcitabine-refractory advanced adenocarcinoma of the pancreas. Ecancermedicalscience. 2015;9:563.

90. Suleiman Y, Mahipal A, Shibata D, Siegel EM, Jump H, Fulp WJ, Springett GM, Kim R. Phase I study of combination of pasireotide LAR + gemcitabine in locally advanced or metastatic pancreatic cancer. Cancer Chemother Pharmacol. 2015;76(3):481-7.

\section{Submit your next manuscript to BioMed Central and we will help you at every step:}

- We accept pre-submission inquiries

- Our selector tool helps you to find the most relevant journal

- We provide round the clock customer support

- Convenient online submission

- Thorough peer review

- Inclusion in PubMed and all major indexing services

- Maximum visibility for your research

Submit your manuscript at www.biomedcentral.com/submit

) Biomed Central 